\title{
ENGLISH CORPORATION LAW IN THE 16TH AND 17TH CENTURIES.
}

\author{
W. S. HoLDSWORTH \\ St. John's College, Oxford
}

During this period the 'medieval principles which regulated this branch of the law were worked out in considerable detail. The largest part of the law still centered round the boroughs and various ecclesiastical corporations sole or aggregate. But hospitals ${ }^{1}$ and colleges had begun to increase; and, at the end of this period, commercial corporations were assuming a position of great importance. They would have continued to increase more rapidly, and, in consequence, the law on this topic would have developed much more quickly, had not the legislature, as a result of the episode of the 'South Sea Bubble,' deliberately made the assumption of corporate form by these societies difficult. ${ }^{2}$ In fact the law developed during this period very much on medieval lines. I shall consider its development under the following heads: the Creation of Incorporate Persons; their Powers, Capacities and Liabilities; their Dissolution; and the Nature of Corporate Personality.

TEE CREATION OF INCORPORATE PERSONS

The rules as to the creation of the incorporate person had been ascertained in the medieval period. ${ }^{3}$ Coke summed up the medieval rules and laid down the modern rule, when in the Case of Sutton's Hospital he stated that the first essential for a vital corporation was a "lawful authority of incorporation," and explained this to mean that a corporation must be created either by the common law, by authority of Parliament, by royal charter, or by prescription. ${ }^{4}$ To this we must add that,

\footnotetext{
1 "The legal sense of the word hospital is a corporate foundation, endowed for the perpetual distribution of the founder's charity, in the lodging and maintenance of a certain number of poor persons, according to the regulations and statutes of the founder. Such institutions are not necessarily connected with medicine or surgery, and in their original establishment had no necessary reference to sickness or accident," Grant, Corporations (ed. I850) 567; as is there pointed out they did not differ very materially from colleges; in the case of the college education of poor persons was the main object, and in the case of the hospital their maintenance. Ibid.

${ }^{2}$ See an article by the present writer (I9I6) 28 Scot. JuRID. REV. 343.

\& 3 Holdsworth, History of English Law (rgog) 373.

- "Lawful authority of incorporation; and that may be by four means, sc. by the common law, as the King himself, etc.; by authority of Parliament; by the King's charter (as in this case) ; and by prescription," Case of Sutton's Hospital (I6I3, K. B.) 10 Co. Rep. Ia, $29 \mathrm{~b}$.
} 
as in the medieval period, a corporation for a limited purpose could be created by implication. ${ }^{5}$

The need for the sanction of the state for the creation of a corporation was steadily adhered to in this period, and it has never been abandoned. It was adhered to on those grounds of public policy which I have elsewhere explained ${ }^{6}$ and their existence is assumed in all the cases of this period. Perhaps the earliest case in which they are explicitly stated is the case of the quo warranto proceedings against the City of London in I682. ${ }^{7}$ Sir Robert Sawyer, the Attorney-General, was arguing that corporations which abused their power could be seized into the king's hands. If, he said, it were impossible to proceed thus against corporations, and to punish them for their misdeeds, "it were to set up independent commonwealths within the kingdom and (this) ... would certainly tend to the utter overthrow of the common law, and the crown too, in which all sovereign power to do right both to itself and the subjects, is only lodged by the common law of this realm." $\mathrm{A}$ mere permission to aggrieved individuals to sue the corporation would be of little avail "whilst the cause still remains and is in as great power to oppress as before." Indeed "the law would be deficient if such inferior jurisdictions, or corporations, were not subject to the common law upon the like conditions, as other liberties, franchises and inferior jurisdictionš are."

That is really the gist of the matter. The same reasons which make it necessary for the law to recognize the crime of conspiracy, make it necessary to regulate these groups of men who, when they act in combination, have far more power for good or evil than any single man. The failure to recognize this principle in the case of the trade union, and the abandonment by the state of any control over their activities, have shown that Sir Robert Sawyer was a true prophet; 'for the abandonment by the state of its sovereignty has in effect set up a new feudalism which is every bit as retrogressive in its ideas and as mischievous as the feudalism of the Middle Ages. Our modern experience is a striking illustration of the political wisdom of the Roman lawyers when they taught the expediency of "keeping the corporate form under lock and key." In fact creation by and subordination to the state are the only terms upon which the existence of large associations of men can be safely allowed to lead an active life.

It is, it is true, a favorite theory among our modern teachers of jurisprudence that the life of these associations of men is a real living

'Anonymous (I553, Q. B.) I Dyer, 100 a.

- 3 Holdsworth, op. cit. 373-5.

( (I682, K. B.) 8 S. T. 1039 .

Ibid. Ir78.

- Maitland, Gierke on Political Theories of the Middle Age (I900) xxx. 
thing quite independent of the permission to exist as an incorporate person given to them by the state; and a survey of the various groups which flourished in the Middle Ages, a consideration of the great freedom with which groups may incorporate themselves at the present day, may lead to the view that these incorporate groups have, and always have had, a life of their own, independent of the sovereign state, just as the custom which is at the back of law is independent of the command of the sovereign. The practical inference sometimes drawn seems to be that the law should recognize the personality of all such groups. But it is obviously inexpedient to limit unduly the sovereign's power to impose conditions upon such recognition. The sovereign may be willing to recognise many various groups, just as he may be willing to recognise as law many reasonable customs. But a civilized state cannot dispense either with the need for that recognition or with the power to impose conditions, any more than it can dispense with some test as to the reasonableness of the customs which it admits as laws. The somewhat anarchic theory that the sanction of the state could or should be dispensed with, has gained more favor in Germany and other continental countries than in England, because the attainment of corporate form was, as Maitland has shown, more eagerly desired in countries which had not the expedient of the trust. ${ }^{10}$ Much can be done under cover of a trust without the necessity of a grant of incorporation. And though it has been necessary to control the formation of these trusts in certain respects, a greater liberty of forming them can more safely be allowed than a large unregulated liberty of association, because the capacity for action of a group of men, who depend for their life upon a body of trustees acting under a trust deed which defines and stereotypes their powers, is far more limited both for good and evil than the capacity for action of an incorporate person.

Corporate life and form therefore cannot exist without the permission of the state, express, presumed, or implied. But the incidents of the continuance of that life are not equaliy dependent on the state. An Act of Parliament can of course do anything; so that it can give a corporation powers which, without such a sanction, would infringe the principles of the common law ; or it can vary its powers, or dissolve it at pleasure. But it was well recognized in the seventeenth century that

\footnotetext{
10 "Behind the screen of trustees, and concealed from the direct scrutiny of legal theories, all manner of groups can flourish: Lincoln's Inn or Lloyd's or the Stock Exchange or the Jockey Club, a whole presbyterian system, or even the Church of Rome with the Pope at its head. But, if we are to visit a land where Roman law has been 'received,' we must leave this great loose 'trust concept' at the Custom House, and must not for a moment suppose that a meagre fidei commissum will serve in its stead. Then we shall understand how vitally important to a nation-socially, politically, religiously important-its Theory of Corporations might be." Maitland, op. cit. xxix, sxx.
} 
the law cannot be changed by royal charter, ${ }^{11}$ so that a charter which purported to give a corporation powers which infringed the principles of the common law would be void. ${ }^{12}$ It would seem, for instance, that a charter which permitted a corporation to deprive at will any of the corporators of his freehold rights in the corporation would be void $;^{13}$ and it was held after the Revolution that new charters granted after an attempted surrender of the old charter which could not take legal effect, were void. ${ }^{14}$ It would seem, too, that the king could not at his pleasure vary the rights of those upon whom he had conferred privileges by his charter, ${ }^{15}$ nor could he dissolve the corporation which he had created..$^{16}$

These principles are clearly the consequence of the definition of the constitutional position of the king in the state. Obviously they made for the independence of the corporate life which these incorporate persons enjoyed, just as they made for the freedom of the natural persons who were the subjects of the state. We shall see in the following section that they have had some influence on the character of the powers, capacities, and liabilities which the law attributed to them.

POWERS, CAPACITIES, AND LIABILITIES

In the Middle Ages the lawyers were beginning to deduce from the nature of corporate personality certain conclusions as to the powers, capacities, and liabilities of corporations. ${ }^{17}$ This process was pursued during this period; and, in consequence, we find certain rules laid down as to activities from which the nature of that personality debarred corporations, and as to activities which were naturally incident to corporate life. But we shall see that, though it is possible to say that the nature of corporate personality debars corporations from certain activities, it is difficult to draw the line in particular cases; and from that time to this there has been considerable fluctuation of opinion as to whether or no certain activities are or are not permissible. Similarly there has been considerable difficulty in determining what activities are or are not incident to corporate life; and, in the evolution of the law on this matter, the disturbing influence of semi-political considerations may be suspected. Most corporations at this period were created by royal

"The king cannot by his charter alter the law." Anthony Lowe's Case (1610, K. B.) 9 Co. Rep. I22b, I23a.

${ }^{12}$ In the Middle Ages this principle had been applied to a charter which, it was alleged, had infringed a statute. Select Cases before the Council (s.s.) 6I, 62, $66,68,69$.

${ }^{13}$ See Warren's Case (1620, K. B.) Cro. Jac. 540; Grant, Corporations (ed. 1850) 22.

"Piper v. Dennis (1692, K. B.) Holt, I70; Grant, op. cit. 2I-2.

${ }^{15}$ City of London's Case (I6ro, K. B.) 8 Co. Rep. I2Ib, I26b, citing a record of 32 Edw. III.

${ }^{10}$ Hayward v. Fulcher (1624, K. B.) Palmar, 491, 50r, per Whitlock, J.

${ }^{17} 3$ Holdsworth, History of English Law, 369-7r. 
charter; and, as we have seen, ${ }^{18}$ to allow a royal charter to vary the incidents annexed by the common law to corporate capacities appeared to contravene the principle that a royal charter cannot change the law. Hence there was a tendency to define corporate powers and capacities somewhat rigidly, and to deny that the crown could limit the powers naturally incident to a corporation. But it was obviously desirable to maintain some measure of control over corporate activities. This fact was recognized by the law; and it soon became apparent that, as the purposes for which corporations were formed were very various, it was hardly possible to maintain that all corporations created by royal charter must have the same powers and capacities. Hence, in addition to older modes of controlling corporate activities, we begin to see the beginnings of a limitation on these activities based upon the purposes for which a corporation is created-a limitation which, in later law, will assume enormous importance. Though it may not be within the competence of the crown to change the incidents annexed by law to corporate personality, it is competent to the crown to define the purposes for which a corporation is created; and if the corporation tries to effect purposes other than those for which it was created, its acts will be ultra vires and void.

I shall therefore deal with the history of this subject under the following three heads:-(I) activities impossible to a corporation; (2) powers and capacities incident to a corporation; and (3) limitations on the powers and capacities incident to a corporation.

(I) Activities Impossible to a Corporation. The deductions which the medieval lawyers had drawn from the nature of corporate personality as to the activities which were impossible to a corporation were summed up by Coke in the Case of Sutton's Hospital, ${ }^{19}$ and passed on into modern law.

"A corporation aggregate of many," he said "is invisible, immortal, and rests only in intendment and consideration of law; and therefore a dean and chapter cannot have predecessor nor successor. They cannot commit treason, nor be outlawed, nor excommunicate, for they have no souls, neither can they appear in person, but by attorney. A corporation aggregate of many cannot do fealty, for an invisible body can neither be in person nor swear. It is not subject to imbecilities, death of the natural body, and divers other cases."20 .

So in 1682 it was said by counsel arguing for the corporation of London that a corporation "is but a name, an ens rationis, a thing that cannot be seen, and is no substance."21 It followed that it could not

\footnotetext{
${ }^{18}$ Supra, at p. 383 . $\quad{ }^{10}$ ( $16 \mathrm{r}_{3}$, K. B.) Io Co. Rep. Ia.

${ }^{20}$ Case of Sutton's Hospital, supra, at p. 32b.; cf. Bevil's Case (1575, Q. B.) 4 Co. Rep. 8a, Ira; Coke, Littleton, 66b.

${ }^{2}$ Proceedings between the King and the City of London (I682, K. B.) 8 S. T. .I039, II37.
} 
either do or suffer a personal wrong, so that it could not commit or suffer a battery; nor could it have a traitorous or a felonious mind, so that it could not commit treason or felony. ${ }^{22}$ In the eighteenth century Blackstone summarized the list of the disabilities of a corporation deduced from the nature of its corporate personality to be found in the older authorities; ${ }^{23}$ and in I9I5 substantially the same views were expressed by Lord Wrenbury. "The artificial legal person called the corporation," he said, "has no physical existence. It exists only in contemplation of law. It has neither body, parts, nor passions. It cannot wear weapons nor serve in the wars. It can be neither loyal nor disloyal. It cannot compass treason. It can be neither friend nor enemy."24

But it is one thing to draw abstract deductions from the nature of corporate personality as to the powers and capacities and liabilities of a corporation; it is another thing to translate these deductions into concrete rules. If they were pushed to their logical conclusions, it would follow that a corporation could not as a corporation be held liable for tort or crime. This consequence followed from the arguments addressed to the court on behalf of the City of London in I682. ${ }^{25}$ But the court was swift to reject it, ${ }^{26}$ and in effect held that a corporation could be guilty of a seditious libel and other misdemeanors. ${ }^{27}$ In more modern times the courts have held a corporation liable even for malicious torts committed in the course of acts which are within the scope of the powers of a corporation. ${ }^{28}$ No doubt the theoretical diffculties of imputing malice to a corporation which were felt by some judges ${ }^{2 \theta}$ and given effect to in some decisions of the nineteenth cen-

\footnotetext{
${ }^{23}$ Ibid. II37-8. $\quad{ }^{2}$ I Blackstone, Commentaries, *476-7.

${ }^{25}$ Continental Tyre and Rubber Co. v. Daimler [1915, C. A.] I K. B. 893, 916.

${ }^{25}$ See Proceedings between the King and the City of London, supra note 21 , at pp. 1137-40.

${ }^{26}$ "That bodies politic may offend and be pardoned appears by the general article of pardon, I2 Car. 2, whereby corporations are pardoned all crimes and offences. And the Act for regulating corporations, I3 Car. 2, which provides that no corporation shall be avoided for anything by them misdone or omitted to be done, shows also that their charters may be avoided for things by them misdone, or omitted to be done. Ibid. r266-8.

${ }^{27}$ As Sir F. Pollock says: "Treby's interest, of course, was to suggest every possible objection, technical as well as substantial, to penal proceedings against a corporation. The King's advisers, on the other hand, were prepared to go very far in ascribing both wrongful acts and wrongful intention to a corporate body, for they charged the City of London with a malicious and seditious libel. No general inference can be drawn except that there was no settled rule either way to prevent either argument from being plausible." Pollock, Theory of Corporations in Common Law (I9II) 27 L. QUART. REv. 2I8, 23I-2.

${ }^{28}$ Barzerick v. English Joint Stock Bank (1867) I. R. 2 Exch. 259; Citizens Life Assurance Co. v. Brozen [1904, P. C.] A. C. 423, 426, per Lord Lindley.
}

${ }^{*}$ See e.g. Lord Bramwell's judgment in Abrath v. N. E. Ry. (1886, H. L.) I. R. II A. C. $247,250-4$. 
tury, ${ }^{30}$ have been slurred over by the modern doctrine of an employer's liability for the torts of his agent. ${ }^{31}$ The human agent can be guilty of malice; and, if he acting in the course of his employment, there is no reason why his master should escape liability for his acts because he is a corporation. ${ }^{32}$ It would thus seem that so far as criminal or civil liability is concerned the courts have always been prepared to hold that a corporation is as capable of being held liable as a natural person. It is true that it cannot be punished in the same way as a natural person. It cannot be corporally punished; but its liability can be brought home to it in a manner which is appropriate to such a person. As we shall see it can be dissolved or suspended $;^{\mathbf{3 3}}$ and, as the cases show, it could always be made to pay compensation for the trespasses, ${ }^{34}$ and in our modern law even for the malicious torts ${ }^{35}$ committed by it through its agents.

The manner in which the law has dealt with the liability of a corporation for wrongdoing is typical of the manner in which it has reconciled the incapacities of a corporation which flow from the conception of corporate personality with considerations of practical convenience. At an earlier period in the history of the law, when as yet the idea of a corporation was new, the lawyers were inclined to lay more stress upon wide general deductions from the nature of colporate personality. Thus they said that a corporation could not be seised to a use, ${ }^{36}$ either because a corporation had no conscience or because the process of the Court of Chancery could not issue against it, ${ }^{3 \pi}$ or because it had no

${ }^{30}$ See e. g. Stevens v. Midland Counties Ry. (1854) 1o Exch. 352, 356, per Alderson, B.; Western Bank of Scotland v. Addie (I867) L. R. I Sc. \& Div. I45, I67, per Lord Cranworth.

${ }^{31}$ Note e. g. that in Steverus v. Midland Counties Ry., supra, at pp. 356-7 Platt, B., thought that a corporation would be responsible for a malicious act of its servant which it had authorized.

${ }^{32}$ As Sir F. Pollock has said: As for the question, 'utrum universitas delinquere possit,' our modern way has been to circumvent it. The real difficulty was to make out how any man, any natural man, could be vicariously liable to pay damages for the wrongful act or negligence of his servant, which he had in no way authorized and might even have expressly forbidden. When this was overcome, the difficulty of ascribing wrongful intention to an artificial person was in truth only a residue of anthropomorphic imagination." Pollock, op. cit. $27 \mathrm{~L}$. QUART. REv. at p. 235.

${ }^{33}$ Infra, at p. 402-403.

"3 3 Holdsworth, History of English Law, 370.

${ }^{35}$ Supra, at p. 387.

${ }^{20}$ Fulmerston v. Steward (I554, K. B.) Plowden, I02, I03; Chudleigh's Case (I589-95, K. B.) I Co. Rep. Ir3a, I22a; cf. Sanders, Uses (5th ed. I844) ii $27 n$.

${ }^{27}$ "It was said that no corporation can be seised to a use, for none can have confidence committed to him but a body natural, who hath reason and is capable of confidence, and may be compelled by imprisonment by order of the Chancellor of England to perform the confidence, for that is the way the party shall take to have it performed, and no corporation which consists of many can be imprisoned, 
capacity to take to another's use $;^{38}$ and Blackstone stated that it could not be a trustee. ${ }^{30}$ Because it could hold only in its corporate capacity for the purposes of the corporation, it was said that a gift to a corporation and another person or another corporation jointly would create, not a joint tenancy, but a tenancy in common; for in such a case the two co-owners held in different capacities. ${ }^{40}$ No doubt these were legitimate deductions from the vague and wide premises on which they were founded. But they were found to be inconvenient in practice. And so, on grounds of practical convenience, they have been evaded or altered. Equity, contrary to Blackstone's dictum, found no difficulty in ruling that a corporation could be a trustee, ${ }^{41}$ and the legislature has recently enabled a corporation to hold jointly with another person or corporation. ${ }^{22}$

In fact, though these wide deductions drawn from the nature of corporate personality have called attention to salient incapacities of corporations as compared with natural persons, they have never been able to stand any severe strain. Practical convenience rather than theoretical considerations have, from the days of the Year Books onward, determined what activities are possible and what are impossible to a corporation. And because the law has always followed this course it was the more possible in these last days, in the supposed interests of national defence, to sacrifice the central doctrine of corporation lawthe distinction between the corporation and its members-in order to affect a British corporation with the consequences of possessing an enemy character. ${ }^{43}$ No doubt there is Year Book authority for the proposition that matters affecting individual corporators may affect the validity of corporate acts ; ${ }^{44}$ but this goes far beyond these decisions. Here we need only note, that, historically, the fact that such a decision was possible illustrates the comparatively small importance which doctrines derived from the nature of corporate personality have had on the law as to what activities are impossible to a corporation. We shall see

and their natural body shall not be imprisoned for the offence of their body corporate, which is another body." Croft v. Howel (1578, K. B.) Plowden, 530, 538 .

${ }^{28}$ Abbot of Bury v. Bokenham (I537, K. B.) I Dyer, 7b, 8b.

29 I Blackstone, Commentaries, $* 477$.

"Littleton, Tenures, sec. 296; Coke, Littleton, *I8gb, *Igoa.

"See Attorney-General v. Landerfield (I744, Ch.) 9 Mod. 286, where the Chancellor said that "nothing was clearer than that corporations might be trustees."

(1899) $62 \& 63$ Vict. c. 20.

${ }^{4}$ Daimler Co. v. Continental Tyre and Rubber Co. [19I6, H. L.] 2 A. C. 307 ; at p. 344 Lord Parker said: "The truth is that considerations which govern civil liability and rights of property in time of peace differ radically from those which govern enemy character in time of war."

" 3 Holdsworth, op. cit. 369, note 7; Pollock, op. cit. 27 L. Quart. REv. at p. 234,235 . 
later that this decision has also some bearing on the theory or want of theory as to the nature of that personality which has always been a characteristic feature of English law. ${ }^{45}$ But at this point we must turn from the consideration of the things which a corporation cannot do to the things which it can. Here too we shall see that the wide general rules with which the law started have been modified to meet practical needs.

(2) Powers and Capacities Incident to a Corporation. Already in the Middle Ages the lawyers were coming to the conclusion that certain powers and capacities were incident to a corporation. It was assumed in $148 \mathrm{I}^{46}$ that a corporation could take a grant of property or franchise, for that was the purpose for which the corporation had been created; and Fitzherbert, in abridging this case, laid it down that if a corporation were created it had by implication the capacity to sue and to be sued. ${ }^{47}$ Coke, improving upon these authorities, laid it down that other powers and capacities belonged to a corporation by necessary implication. For instance the power to acquire or alienate property, and to have a seal, and the right of the survivors to succeed to the corporate property-were all incident to a corporation. ${ }^{48}$ Further, other powers might be given to a corporation, which were necessary to enable it to carry out the purposes for which it was created. Thus it might be given the power to acquire lands in mortmain, or to make by-laws for the better carrying out of the purposes for which the corporation was created. ${ }^{49}$ Blackstone, while admitting that there were distinctions between corporations sole and corporations aggregate, and between ecclesiastical and eleemosynary corporations and others, ${ }^{50}$ lays it down that to every corporation aggregate there is inseparably annexed as of course the following five incidents: I. To have perpetual succession. 2. To sue or be sued, implead or be impleaded, grant or receive, by its corporate name, and do all other acts as natural persons may. 3. To purchase lands and hold them, for the benefit of themselves and their successors. 4. To have a common seal. 5. To make by-laws or pri-

is Infra, at p. 407.

Y. B. 2I Edw. IV, p. 55, p1. 28.

- ${ }^{47}$ Fitzherbert, Abr. Grant, pl. 30 where he makes Brian and Choke say: "que le roy puit faire corporacion sauns rien reserver ou riens dire que il serra pled ou empleder quar le si le roye graunte a moye licens de fayre une chaunterye pour une prest chaunterye en certeyne lieu et doner a luy et ces successours certeyne terre al value de certeine somme, et jeo face, issint il est bone corporacion sauns pluis parolx et sauns riens reserver etc."

' Case of Sutton's Hospital (1613, K. B.) Io Co. Rep. Ia, 30b; as Sir F. Pollock says: "Coke appears to go a little beyond Fitzherbert, and Fitzherbert a little beyond the book at large." Pollock, op. cit. 27 L. QUART. REv. at p. 229.

${ }^{\circ}$ Case of Sutton's Hospital, supra, at p. 3Ia; Norris v. Staps (I6I7, K. B.) Hob. 210, 2Ir.

${ }^{80}$ Blackstone, Commentaries, *469-7I. 
vate statutes for the better government of the corporation, which are binding upon themselves unless contrary to the laws of the land. ${ }^{\text {s1 }}$

It was settled before the sixteenth century ${ }^{52}$ and recognized in that century ${ }^{53}$ that any of the powers belonging to a corporation could be exercised by a majority of the corporators-a principle which an Act of I 54I-2 enforced on corporations notwithstanding any directions to the contrary contained in their foundation statutes. ${ }^{54}$ Similarly the medieval rule that an act of the corporation must be under the corporation seal,,$^{55}$ and the medieval exceptions to that rule ${ }^{56}$ were recognized and reasserted; and it was laid down at the end of the seventeenth century that the seal must be affixed by the proper officer, ${ }^{57}$ and that the seal was not needed for acts which, being matters of record, the corporation was estopped from denying. ${ }^{58}$

All these powers, whether incident or not to a corporation, were giving rise to a large mass of case law. With the detailed rules which resulted we are not here concerned. But we are concerned with the manner in which the law regarded these powers, as it has a considerable bearing upon the view which the law took of corporate powers generally.

It would seem that, just as the law regarded certain powers and capacities to be impossible to a corporation owing to the nature of its corporate personality, so it regarded certain powers and capacities as incident to that personality, and as inseparably annexed to it as to a natural person. This view of the nature of corporate capacities had not emerged in the Middle Ages. It was said, it is true, that a power to sue or be sued was naturally incident to a corporation; and it was assumed that a power to hold property or make contracts was also

${ }^{51}$ Ibid. *475-6.

(I48I) Y. B. 2I Edw. IV, p. 67, 70, p1. 53.

"See the Chamberlain of London's Case (I59r, K. B.) 5 Co. Rep. 62b, 63a; cf. Regina v. Bailiffs of Ipszerich (I706, Q. B.) 2 Salk. 434, 435; Grant, Corporations, 68.

${ }^{54} 33$ Henry VIII, c. 27-a necessary act for avoiding questions as to the validity of the surrenders of the monastic property.

${ }^{s s} 3$ Holdsworth, History of English Law, 370; Grant, op. cit. 55, and cases there cited.

${ }^{\infty}$ But the authority on this matter is scanty; besides the Y.BB. cases, see 3 Holdsworth, $o p$. cit. 370-I. Grant, op. cit. 62 only cites Randle v. Dean (I70I, C. P.) 2 Lut. I496, which has not much bearing on the matter, and Blackstone does not mention these exceptions in his treatment of the subject in Bk. I; but the exception seems to have been recognized in Cary v. Matthezs (1688, Exch. Ch.) I Salk. Igr. It had got into the Abridgments, and as Grant points out, it was revived and given its modern importance by the decisions of the nineteenth century.

${ }^{57}$ Anonymous (I702, K. B.) I2 Mod. 423, per Holt, C. J.

"Mayor of Thetford's Case (I702, Q. B.) I Salk. I92-"The reason is, because they are estopped by the record to say it is not their act." 
naturally incident. But it was not till the sixteenth century that these and the like powers were said to be inseparably annexed and therefore tacitly incident to all corporations. We may perhaps suspect that the analogy of developments of the law relating to the prerogative has had some influence. Talk about inseparable prerogatives was very much in the air; the King had been endowed with a corporate capacity; the law had, as we have seen; already drawn the conclusion that certain activities were impossible to a corporation, and that certain capacities were obviously and naturally incident to it-was it not therefore natural to argue that these capacities were not only naturally incident to a corporation, but as inseparable as similar capacities were to a natural man? And another consideration of a semi ${ }^{2}$ constitutional kind no doubt helped the judges to come to this conclusion. It was well recognized that the king's charter could neither change the common law nor alter the rights and duties of private persons as fixed by law. ${ }^{59}$ To hold, therefore, that the king could neither give nor take away powers from a corporation which he could not give or take away from a natural man was quite in accordance with this constitutional doctrine. ${ }^{60}$ But, if this were so, it followed that these powers and capacities were not only incident, they were also inseparably annexed to a corporation. The result was that any attempt on the part of the crown to restrict these powers could have no legal effect.

This doctrine and its practical results are clearly expressed in the following passage in the Case of Sutton's Hospital: $:^{61}$

"When a corporation is duly created all other incidents are tacitè annexed .... and therefore divers clauses subsequent in the charters are not of necessity, but only declaratory, and might well have been left out. As I. By the same to have authority, ability, and capacity to purchase, but no clause is added that they may alien, etc. and it need not, for it is incident. 2. To sue and be sued, implead and be impleaded. 3. To have a seal, etc., that is also declaratory, . . . 4. To restrain them from aliening or devising but in a certain form; that is an ordinance testifying the King's desire, but it is but a precept, and doth not bind in law."

This principle was according to Lord Raymond's report, partially at

${ }^{\circ}$ See The Prince's Case (1606, Ch.) 8 Co. Rep. Ia, I6b; see also supra note I2, at p. 385 .

${ }^{\infty}$ Cf. Pollock, op. cit. 27 L. QUART. Rev. at p. 230.

${ }^{1}$ ( $1613, \mathrm{~K}$. B.) 1o Co. Rep. Ia, 30b. On this question see Carden, Limitations on the Powers of Common Law Corporations (Igro) 26 L. QUART. Rev. 320, which contains a very full and suggestive account of the evolution of the law on this matter.

az "There are two sorts of corporations. The one constituted for public govern-ment, the other for private charity. The first being duly created, although there are no words in their creation, for enabling their members to purchase, implead, 
any rate accepted by Holt, C. J., in $I 694{ }^{62}$ and the same view is stated even more strongly by Blackstone. ${ }^{63}$

Now it is clear that this doctrine gives to corporations great liberty of action. It means, for instance, that they have the same free power to alienate real and personal property as a natural person; and this consequence has, in spite of adverse criticism of the rule as to free alienation of realty, ${ }^{64}$ been admitted by the courts. ${ }^{65}$ Similarly they have the same freedom of contract, provided that the contract is in the proper form. In 1874 in the case of Riche v. The Ashbury Carriage Co., ${ }^{\text {Bb }}$ Blackburn, J., after citing the passage just quoted from the Case of Sutton's Hospital, said: ${ }^{6 t}$

"This seems to me an express authority that at common law it is an incident to a corporation to use its common seal for the purpose of binding itself to anything to which a natural person could bind himself, and to deal with its property as a natural person might deal with his own. And further, that an attempt to forbid this on the part of the King, even by express negative words, does not bind at law. Nor am I aware of any authority in conflict with this case."

But it is clear that to allow corporations this great liberty of action is not without its dangers. The logical result of allowing it is to give them powers to do acts which may be wholly beyond or even contrary to the purposes for which they were created. It was probably due to these rules of law that, at the end of the seventeenth century, companies were able to cite the opinion of eminent counsel to justify their acts in carrying on trades or businesses or pursuing activities wholly outside the scope of their charters, so that, for instance, a company for the manufacture of hollow sword blades, proceeded to carry on a banking business. ${ }^{68}$ It was probably also a perception of the inconveniences which so unrestricted a power would give to corporation that has induced eminent authorities to question the rule that a corporation may freely alienate its real property. ${ }^{69}$ But in fact, though corporations had these large powers at common law, the law has always provided some measure of control over their exercise. To the consideration of the

or be impleaded, yet they may do all these things, for they are all necessarily included in and incident to the creation." Philips v. Bury (r694, K. B.) I Ld. Raym. 5, 8; but this passage does not occur in Skinner's report of this case at p. 482.

«s "These five powers" (see supra at p. 390) "are inseparably incident to .... every corporation aggregate." I Blackstone, Commentaries, *476.

" Grant, op. cit. I29 et seq. Brice, Ultra Vires (3d ed.) 74-8.

${ }^{\circ 5}$ Baroness Wenlock v. River Dee Co. (1887) L. R. 36 Ch. Div. 674, $685 n$.

${ }^{\infty}$ L. R. 9 Exch. 224.

"Ibid. 263.

es See Holdsworth, op. cit. (I9I6) 28 Scot. JuRID. REv. 336.

${ }^{\infty}$ See note 64 supra. 
form which this control has taken at different periods and in different circumstances we must now turn.

(3) Limitations on the Powers and Capacities Incident to a Corporation. Just as all natural persons are subject to the common law, so, from the earliest times the common law has enforced its rules on all groups and communities of persons. We have seen that in the early days of the common law this control had a considerable share in moulding these various groups and communities through which the local government of the country was carried on. ${ }^{70}$ Naturally it exercised the same control over some of these groups when they became municipal corporations. These corporations were simply the old borough communities incorporated. ${ }^{11}$ They could not be said to have any distinct founder; and so they were said to be subject only to the "general and common laws of the realm."72 This expressed the historic truth as to the form of control to which these corporations had been subject from time immemorial. Taken in connection with the doctrine as to the wide powers inseparably incident to a corporation, it in practice left these corporate bodies an undue freedom which produced that state of mind which is illustrated by the defence of the Cambridge common councilman to the charge that the corporation had been selling pieces of the corporation land to corporators at unduly low prices-"he thought that the property (of the corporation) belonged bona fide to the corporation and that they had a right to do what they pleased with their own."?s In later law this rule was expressed in the unhistoric form that these corporations, not being subject to any visitor, were subject to the visitation of the king which was exercisable only in the court of King's Bench. ${ }^{74}$ And this rule was extended to all corporations; so that a clause in letters patent subjecting a corporation to the visitation of others was held in 1753 to be void. ${ }^{75}$

This somewhat unhistoric manner of stating the law was due to the fact that ecclesiastical and eleemosynary corporations were always subject to the control of a visitor. These were the earliest corporations; and, till the modern growth of trading corporations, they were perhaps the most numerous and not the least important of corporations.

${ }^{30} 2$ Holdsworth, History of English Law, 279-84, 335-6.

${ }^{71}$ Maitland, Tozenship and Borough, I9-20.

${ }^{72}$ Philips v. Bury (r694, K. B.) I Ld. Raym. 5, 8, per Holt, C. J.

${ }^{73} 4$ Municipal Corp. Report, 2x99, cited Maitland, Tozwnship and Borough, I2.

74 "In general, the king being the sole founder of all civil corporations.... the right of visitation .... results .... to the king. The king being thus constituted by law the visitor of all civil corporations, the law has also appointed the place, wherein he shall exercise this jurisdiction: which is the court of king's bench; where, and where only, all misbehaviours of this kind of corporations are enquired into and redressed, and all their controversies decided," I Blackstone, Commentaries, *48I.

${ }^{75}$ Ibid. $48 \mathrm{r}$. 
During this period the law was well established that ecclesiastical corporations were liable to visitation by the bishop; and that, subject to any other appointment by the founder, lay corporations of an eleemosynary type were subject to the visitation of the founder and his heirs. $^{76}$ The powers and duties of these visitors were settled, and put on their modern basis by the decision of Holt, C. J., in the case of Phillips v. Bury in $1694::^{77}$

"The office of visitor by the common law is to judge according to the statutes of the college, to expel or deprive upon just occasions, and to hear appeals of course. And from him, and him only, the party grieved ought to have redress; and in him the founder hath reposed so entire confidence that he will administer justice impartially, that his determinations are final, and examinable in no other Court whatsover."78

The control exercised by the visitor was supplemented by the control which the Court of Chancery exercised, from the sixteenth century onwards, over charitable trusts. ${ }^{78}$ In fact, whenever a trust could be established, that Court could intervene to compel a corporation, as it could compel an individual, to carry it out. ${ }^{80}$

But this control was only exercisable when a trust could be established. And in the case of many corporations-municipal corporations and trading corporations for instance-there was no trust to give rise to the interference of the Court of Chancery. In fact none of these methods of control were applicable to lay corporations of a non-eleemosynary type. This fact is illustrated by the provisions of the statute of $1437^{81}$ which gave justices of the peace control over ordinances made by gilds and other similar bodies; and by the statute of $I_{502^{82}}$ which required the consent of the chancellor, the treasurer, the chief justices or judges of assize, or any three of them to ordinances made by crafts, gilds, mysteries, or fraternities. But these statutes went a very little way towards controlling the activities of these corporations. What was wanted was a control which should ensure that they used their powers in furtherance of the purposes for which they had been created. Having regard to the doctrines as to the large powers incident to a corporation, the construction of such a body of doctrine was not easy; for, as we have seen, it seemed to follow from this doctrine, that restrictive clauses in their charters, which purported with this object to restrain their powers, would be void..$^{83}$

\footnotetext{
${ }^{20}$ Case of Sutton's Hospital (1613, K. B.) Ia Co. Rep. Ia, 3та; Eden v. Foster (I725, Ch.) 2 P. Wms. 325, 326; I Blackstone, Commentaries, *48o.

"I Ld. Raym. 5.

"See Eden v. Foster, supra note 76.

${ }^{\infty}$ See Attorney General v. Foundling Hospital (I793, Ch.) 2 Ves. Jr. 42.

${ }^{81}$ I5 Henry VI, c. 5.

${ }^{83}$ See supra, at p. 392; cf. Carden, op. cit. 26 L. QuarT. Rev. at p. 324-6.
} 
We can see the remote origins of the method which will ultimately be devised to deal with this difficulty in a dictum of Brian, C. J., in I48I. "If," he said, "the king grants to the men of Islington that they shall be discharged of toll, that is a good corporation for this purpose; but it will not give them power to purchase, etc." 84 Similarly in 1553 it was said that, "if the queen at this day would grant land by her charter to the good men of Islington, without saying, to have to them, their heirs, and successors, rendering a rent, this is a good corporation for ever to this intent alone, and not to any other, ... ${ }^{85}$ At the time when these statements were made it is probable that the idea that a corporation must have certain powers inseparably incident to it had not yet been laid down so rigidly as it was laid down subsequently. ${ }^{86}$ We may therefore regard the idea that the powers of a corporation were limited by the purposes for which the corporation was created, as an idea which was accepted by the law before the idea that certain powers were inseparably incident to a corporation became an accepted legal doctrine. Historically, therefore, it can be maintained that the latter idea must be understood subject to the former, and that the former idea consequently qualifies the generality of the latter. The former idea was understood to operate in this way by Rolle, who states it as a proposition which qualifies the general proposition that when a corporation is created all other incidents are tacitly annexed. ${ }^{87}$ It followed, therefore, that, though a corporation has a general power of contracting and of dealing with property like a natural man which cannot be restrained by royal charter, yet the fact that it is created for certain purposes will limit its general powers and capacities, by avoiding acts done which are not in furtherance of these purposes.

But, though the law was accepted in this sense in the sixteenth and seventeenth centuries, it rested on somewhat slender authority; it had not as yet been appealed to to invalidate corporate acts; and, in view of the much greater stress laid upon the doctrine of powers inseparably incident to a corporation, it was largely ignored, and, as we can see

\footnotetext{
s "Si le Roy grant hominibus de Islington que ils seront discharges de toll, cest bon corporacion a cest entent, mes nemy a purchaser etc." (I48I) Y. B. 2 I Edw. IV, p. 59 , pl. 28 .

${ }^{85}$ (I553, K. B.) I Dyer, I00a.

See supra, at p. 392.

${ }^{87}$ "Quant un corporation est duement create touts auters incidents sont tacite annexe. Come si le Roy fait un generall Corporation per un certein nosme, sans ascun parolls de licence a purchaser terre, ou implede ou destre implede, uncore le Corporation poet purchace, impledo ou d'estre implede assets bien, pur ceo que per fesans del Corporation touts ceux necessarie incidents sont included. Mes le Roy poet faire per special parolls un limited Corporation ou un Corporation pour un special purpose, come sil grant probis hominibus de Islington et successoribus suis rendant rent; Ceo est un Corporation a render le rent al Roy et nemy autrement," Rolle, Abr. tit. Corporations, G. I-3.
} 
from the Parliamentary enquiry which followed upon the bursting of the South Sea Bubble, even denied to be law. ${ }^{88}$ But the principle was asserted and given somewhat of its modern importance on that occasion; for it was clearly laid down that a corporation could not engage in activities which were wholly foreign to the purposes for which they had been incorporated. ${ }^{89}$

This view of the capacities of corporations was also being reached by a consideration of the limitations on the power incident to a municipal corporation to make by-laws. The common law had long been accustomed to supervise the law administered in the boroughs, and to pronounce upon the reasonableness of their customs and by-laws. ${ }^{90}$ It is clear that during this period the court, in considering the validity of these by-laws of boroughs, had begun to lay stress, not only on their reasonableness, but also on the question whether these by-laws came within the scope of the corporate powers. Thus in 1682, in the case against the City of London, Sir Robert Sawyer, the Attorney-General, speaking of municipal corporations, said : ${ }^{91}$

"The limits and extents of their corporations and jurisdiction are limited by their charters . . . the power of making by-laws, which is incident to a corporation, is only for better government; and by that rule they must be judged."

Substantially the same law was laid down by Holt, C. J., in I700;22 and, during the eighteenth century, it was held both in Chancery and at common law that if a charter gave a corporation power to make by-laws, it could only make them in the cases in which they were enabled to make them by charter, "for such a power given by the charter implies a negative that they shall not make by-laws in any other cases." "Corporations," said Yates J. in I766, "cannot make by-laws contrary to their constitution. If they do they act without authority."

Thus the principle that the activities of corporations must be restrained to the fulfilment of the purposes for which they were created was made to limit the doctrine that certain powers were necessarily incident to a corporation. That doctrine, as we have seen, has resulted

See Holdsworth, op. cit. 28 Scot. JuRid. REv. 336-7, 341-2.

Ibid.

${ }^{90} 2$ Holdsworth, History of English Law, 283.

${ }^{21}$ (I682) 8 S. T. II58-9.

92 "The corporation having power to make bye-laws for the well governing of the city, that ought to be the touchstone, by which their bye-laws ought to be tried; and if it be for their benefit, the bye-law will be good," City of London v. Vanacker (I700, K. B.) I Ld. Raym. 496, 498.

${ }^{93}$ Child v. Hudson's Bay Co. (I723, Ch.) 2 P. Wms. 207, 209, per Lord Macclesfield.

${ }^{2}$ Rex v. Spencer (I766, K. B.) 3 Burr. 1827, I839. 
in giving to corporations a large freedom of action; but the growth of this limiting principle has imposed upon it a necessary and salutary restraint; and the growth in the number and variety of corporations, not otherwise restrained, showed the courts at the end of the seventeenth century that it was absolutely essential to insist upon it. We may say therefore that corporations hold their powers and capacities subject to what in later law will be known as the doctrine of ultra vires. The germs both of the law as to the powers and capacities naturally incident to a corporation, and of the supplementary doctrine of ultra vires have been implicit in the law from an early period. Both began to be developed during this period and in the eighteenth century; but they were not as yet highly developed. It will not be till the nineteenth century that the doctrine of ultra vires will develop into a large body of complex rules $;^{95}$ and then it will be in relation rather to new statutory corporations than to these older common-law corporations. Even at the beginning of the twentieth century the application of the doctrine to the powers of these common-law corporations will give rise to some legal problems to which the authorities give no very certain answer..$^{96}$

We shall now see that these rules as to the extent of the powers of a corporation have some bearing upon some of the modes in which a corporation can be dissolved.

DISSOLUTION

I shall consider first the various modes in which a corporation may be dissolved, and secondly the effect of dissolution on corporate rights and liabilities.

(I) Modes of Dissolution. The modes of dissolving a corporation which were recognized during this period were: first, the disappearance of all its members or of an essential member; secondly, surrender by the corporation of its charter; and thirdly, forfeiture.

(i) The view that, if all the members of a corporation disappeared, the corporation came to an end was the best supported view in the Middle Ages; ${ }^{87}$ it was assumed to be correct by Coke; 98 and it has, therefore, become an accepted principle of the modern law as to common-law corporations.99 It is however by no means a self evident rule $;^{100}$ and it was not the rule of Roman law. ${ }^{1}$ It seems also to have

\footnotetext{
${ }^{95}$ See Brice, Ultra Vires (3d ed.) 37.

${ }^{96}$ See Carden, op. cit. 26 L. QUART. REv. 320.

${ }^{27} 3$ Holdsworth, History of English Law, 370, note I.

"If land holden of J. S. be given to an Abbot and his successors; in this case if the Abbot and all the convent die, so that the body politick is dissolved, the donor shall have again the land, and not the lord by escheat." Coke, Littleton, *I3b.

I Blackstone, Commentaries, *485; Grant, op. cit. 303.

${ }^{100}$ Salmond, Jurisprudence (2d ed. rgo7) 268.

${ }^{1}$ Dig. 3, 4, 7, 2; Girard, Droit Romain (3d ed. 1903) 23 r.
} 
been accepted as a rule of law that if an integral part of a corporation disappears, and there is no power in the others to replace him, the corporation is dissolved. This was the view taken by Rolle in the seventeenth century ${ }^{2}$ and seems to have been the view taken by Parker, C. J., in $1712,{ }^{3}$ and by Comyn in his Digest. ${ }^{4}$ So far was this carried that it was held that, if a municipal corporation omitted to elect its mayor on the right day, so that it lost all power to provide itself with a head, the corporation was dissolved..$^{5}$ This was remedied by an Act of $1724 ;^{6}$ and the fact that this Act was needed is good evidence that at common law the loss of an integral part of the corporation without power of replacement operated as a dissolution. The Act only remedied one consequence of this doctrine in the case of one kind of corporation. But we shall see that the dissolution of a corporation entailed the very inconvenient consequence that all its rights and liabilities disappeared. ${ }^{7}$ It was, therefore, obviously impolitic to allow corporations to be dissolved by carelessness or accident; and so, in the eighteenth century, the courts, in order to avoid this result, extended the older cases which laid it down that acceptance of a new charter did not destroy the old corporation, ${ }^{8}$ and recognized that the crown by a new grant could revive an old corporation thus dissolved. ${ }^{\circ}$

(ii) During the whole of the sixteenth and seventeenth centuries the effect of a surrender by a corporation of its possessions or its charter was extremely doubtful. The fact that the law was doubtful is illustrated by the care which Henry VIII took to get the surrenders of the monastic and chantry lands confirmed by Act of Parliament; ${ }^{10}$ and, at the end of the seventeenth century, the attack by Charles II and James II on the charters of the municipal corporations, and the surrenders of the charters which they procured, gave the law as to the effect of such surrenders a political interest.

\footnotetext{
${ }^{2}$ Abr. tit. Corporation I. pl. i.

Regina v. Ballivos (I7I2, K. B.) I P. Wms. 207, 210-rr.

- Franchises (G. 4).

' Case of the Corporation of Banbury (I7I6, K. B.) ro Mod. 346; I Blackstone, Commentaries, ${ }_{4} 485$.

'II George I, c. 4 .

'Infra, at p. 405.

'Haddock's Case (I68I, K B.) T. Raym. 435, 439; Mayor of Scarborough v. Butler (I685, C. P.) 3 Lev. 237.

- Mayor of Colchester v. Seaber (I766, K. B.) 3 Burr. I866; Rex v. Pasmore (I789, K. B.) 3 T. R. I99, 24I ; Grant, op. cit. 304-5, says: "There seems to be a difficulty in reconciling the doctrine of dormancy, or dissolution for some purposes only, with strict principles of corporation law; on the other hand, however, the inconvenience of holding that a corporation in such circumstances is wholly dissolved, so that their leases would be disturbed, and persons having debts due to them from the corporation could not recover them . . . . is manifestly so great, that the doctrine . . . must probably be considered as almost established."

${ }^{10}$ (I539) 3I Henry VIII, c. I3; (1545) 37 Henry VIII, c. 4.
} 
At the outset we must distinguish between a surrender by a corporation of its property and a surrender of its charter.

It seems to have been the opinion of Fitzherbert that a surrender by a monastery of its lands did not extinguish the corporation; but Brooke took the opposite view ; ${ }^{11}$ and of his opinion were Popham, C. J., and the court of Queen's Bench in the case of The Dean and Chapter of Norzich in I590. They held that "by the grant of all the possessions of a dean and chapter their corporation is determined, inasmuch as they ought to have a place for their assembling." ${ }^{2}$ But, according to Coke's report, on a reference to Egerton, the two chief justices, and the chief baron, it was held in 1598 , in accordance with what would seem to have been Fitzherbert's opinion, that, if the corporation had duties to perform, which they could perform without possessions, the mere surrender of their possessions did not dissolve the corporation $;^{13}$ and this is the view which has prevailed. Thus Holt, C. J., pointed out in 1692 that a surrender of liberties and privileges did not dissolve a municipal corporation, as it still had duties to fulfil, i. e. the government of the town..$^{14}$ If, on the other hand, the surrender of its property entailed the total impossibility of carrying out the purpose for which the corporation was created the surrender of the property might mean the dissolution of the corporation. ${ }^{15}$

Right down to the Revolution the question of the effect of a surrender by a corporation of its charter was very uncertain. Two cases of $1568^{16}$ and $1569^{17}$ reported by Dyer could be cited for the proposition that a surrender of the charter would dissolve the corporation. The first case is not very strong because the point was rather assumed than decided, and there had been legislation confirming the surrender; but in the second, four judges gave it as their deliberate opinion that a

\footnotetext{
"1 "Labbe et touts les moygnes devie, le Corporation est dissolve, et le terre eschetera, tamen 32 H. 8 per Fitzherbert, si ils vend tout les terres et labbey uncore le corporation remayn, quaere de que il serra abbe, car la est nul eglise ne monastarie, quaere si labbe devye si ils poyent eslire auter, le meason estant dissolve, moigne et chanon sont capaces des spiritualities come destre vicar executor et hujusmodi," Brooke, Abr. tit. Corporations pl. 78; the meaning of the last sentence would seem to be that, the monastery being dissolved, the monks are no longer dead persons in the law.

${ }^{12} 3$ Dyer, 273b.

${ }^{23}$ Dean and Chapter of Norwich's Case (I598, Ch.) 3 Co. Rep. 73a; see at ff. 75a, 75b; followed by Hayzward v. Fulcher (1628, K. B.) W. Jones, I66, r68.

"Rex $v$. The Mayor of London (1692, K. B.) I2 Mod. I7, I9.

${ }^{15}$ "He agreed, that if a corporation were made to a particular purpose, and they devest themselves of all right, so that they cannot answer the end of their institution, it is thereby dissolved." Ibid. So Coke said: "There cannot be a warden of a chapel, if the chapel and all the possessions be aliened .... because he cannot be warden of nothing." (I598) 3 Co. Rep. at f. 75 .

${ }^{10}$ Walrond v. Pollard (I568, K. B.) 3 Dyer, 273 a.

${ }^{17}$ Archbishop of Dublin v: Bruerton (I569, K. B.) 3 Dyer, 282b.
} 
surrender of its charter by a corporation dissolved it. But later the current of opinion set the other way. In 1598 the inference drawn from the case of 1568 was that the surrender "was not thought sure, till the grant and surrender was established and confirmed by Act of Parliament; ${ }^{18}$ and in $I 628$ Whitlock, J., differing from Jones, J., was strongly against the view that a corporation could dissolve itself by such a surrender-a corporation which did such an act would, he said, be "as it were a felo de se, which is against nature."1s Naturally these different opinions were the subject of much argument in the proceedings against the City of London in $1682 ; ;^{20}$ and, since many corporations were induced to surrender their charters to James II and accept new ones, the question of the effect of a surrender assumed and became a question of political importance. That the law was very doubtful, and that most of the judges could not wholly free themselves from their political prepossessions, is clear from the opinions which they gave to the House of Lords in I690, when a bill for the restoration of corporations was before the House. ${ }^{21}$ Most of the judges held that a corporation could not surrender ;22 but Holt, C. J., followed by Eyre, J., held that it could.

"Whether," he said, " a corporation may be legally surrendered is a question that has lately been debated in Westminster Hall. I am of opinion that a corporation may surrender, and thereby the corporation is dissolved. I take it to be a franchise from the crown and may be surrendered. It is a creature created by policy. Where is the harm if the king consents and the corporation too? A corporation is made for need; in times they are not fit." 23

Then, after citing the two cases reported by Dyer, he proceeded, "Some say this (i. e. a corporation) is but a capacity. This is more; this is an entity; they have power to act." As was generally the case, it is Holt's view that has prevailed ; ${ }^{24}$ but with this qualification that, if the corporation is a corporation by prescription ${ }^{25}$ or created under the authority of an Act of Parliament, ${ }^{26}$ it cannot dissolve itself by the surrender of its charter. In the first case it has no charter to surrender, and in the second it does not derive its being from the charter.

(iii) That a corporation could be suspended or dissolved on pro-

${ }^{23}$ Dean and Chapter of Norwich's Case (I598, Ch.) 3 Co. Rep. 73a, 75b.

"Hayzoard v. Fulcher (I628, K. B.) Palmer, 49I, 50I; see a discussion of these and other relevant authorities in (I682) $8 \mathrm{~S}$. T. at pp. 1283-8.

${ }^{\circ}$ (I680) 8 S. T. at p. III-3, per Treby arg.

${ }^{21}$ Hist. MSS. Comm. I2th Rep. App. pt. vi. no. 208 at pp. 429-32.

${ }^{2}$ See the views of Pollexfen, C. J., at pp. 429-30.

23 At p. 429.

${ }^{24}$ Butler v. Palmer (I700, K. B.) I Salk. I90; Grant, op. cit. 46.

${ }^{23}$ Grant, op. cit. 296, 306-7.

${ }^{20}$ Ibid. $46,308$. 
ceedings taken against it by the crown for misuse or abuse of its, privileges was a very old principle of the common law. The two methods used to effect this object were scire facias and quo warranto; but for the old writ of quo warranto an information in the nature of a quo zvarranto had been substituted. ${ }^{27}$

As in the case of a surrender, so in the case of a forfeiture or suspension of a corporation, the proceedings taken by Charles II and James II against the municipal corporations occasioned much dispute as to the possibility of forfeiture. Those who argued for the City of London maintained the thesis that a corporation could not be "discorporated" as the result of an information in the nature of a quo warranto; ${ }^{28}$ and, after the Revolution, the same judges who denied that a corporation could be dissolved by surrender maintained that it could not forfeit its existence, and the judges who took the opposite view on the question of surrender also took the opposite view on the question of forfeiture. ${ }^{29}$ Here too it is the view of the last named judges which has prevailed. ${ }^{30}$ And it has rightly prevailed for those reasons of public policy which were successfully urged by the counsel who argued for the Crown in the case against the City of London in I682. ${ }^{31}$ It is a great hiatus in our modern company law, a hiatus which has recently been the cause of considerable difficulty, ${ }^{32}$ that no such procedure is applicable to a limited company. ${ }^{33}$

Later cases have drawn a distinction as to when the proceedings by scire facias and when the proceedings by quo warranto are appropriate. It was laid down by Ashhurst, J., in $I 789$ as follows :34

"A scire facias is proper when there is a legal existing body, capable of acting, but who have been guilty of an abuse of the power entrusted to them; for as a delinquency is imputed to them, they ought not to be condemned unheard; but that does not apply to the case of a non-existing body. And a quo warranto is necessary where there is a body corporate de facto, who take upon themselves to act as a body corporate, but from some defect in their constitution they cannot legally exercise the powers they affect to use."

\footnotetext{
${ }^{27}$ The chief difference between the two seems to have been in the mesne process. See Grant, op. cit. 298.

${ }^{23}$ (I682) 8 S. T. at pp. III5, I245.

${ }^{20}$ Hist. MSS. Comm. I3th Rep. App. pt. v. no. 269 pp. 72-3.

${ }^{30}$ Rex v. Mayor of London (I692, K. B.) I2 Mod. 17, I8; Grant, op. cit. 295; cf. 8 Halsbury, Laws of England, 397-8, 400.

${ }^{34}$ See supra, at p. 383 . $\quad$ See infra, at p. 406.

33 "There is no provision for extinguishing a registered company by any formal application analogous to a scire facias to repeal the charter of a chartered company; it can only be extinguished by winding up on certain specified grounds." 5 Halsbury, Lazes of England, 390.

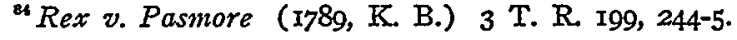


This seems to be the distinction recognised in modern law ;5 but it may be doubted whether it was recognised in the sixteenth and seventeenth centuries or earlier. ${ }^{38}$ There is no doubt that quo warranto proceedings were taken against existing corporations in Edward I's reign; and these proceedings were taken against the City of London in I682. ${ }^{37}$ It is true that Treby, in his argument for the City, maintained that the procedure adopted was impossible because it assumed that the City was a corporation, and yet charged the City with having usurped the name of a corporation $;^{88}$ and he cited a commonplace book of Hale for the proposition that, if a quo zerarranto was brought for usurping the name of a corporation, it must be brought against individuals, though it might be against a corporation for usurping particular liberties to which they were not entitled. ${ }^{39}$ This distinction has not been upheld ; ${ }^{40}$ but it may be that the arguments in the City of London Case, and the subsequent discussions of that case, have had something to do with fixing the modern law.

If judgment is given for the crown on a scire facias the charter is repealed, and the corporation disappears. ${ }^{41}$ On a quo warranto the crown, if successful, got judgment that the corporation be seized into the king's hands. This does not necessarily dissolve, but may only suspend the corporation. If the crown chooses to take advantage of the seizure and does not restore its rights the corporation will be dissolved. But he may restore its rights or revive them by a new charter, in which case the result of the seizure will only be suspension; and this in fact has been the usual course pursued in such cases. ${ }^{42}$ We shall now see that some of the effects of dissolution supply a very good reason why the king should in such cases choose to revive the old corporation, rather than let it be dissolved, and create a wholly new corporation.

(2) The Effect of Dissolution on Corporate Rights and Liabilities. At the close of the Middle Ages it was doubtful whether, on the dissolution of a corporation, its real property escheated, or whether it reverted to the donor. ${ }^{43}$ There is no doubt that the former view is the more logical; and there is reason to think that this view was taken in I622. ${ }^{44}$ The latter view was probably, in origin at least, based upon

${ }^{*}$ Grant, op. cit. 296; 8 Halsbury, Laws of England, 400.

${ }^{36}$ Grant, op. cit. 296-8.

${ }^{23}$ (I682) $8 \mathrm{~S}$. T. at p. III6.

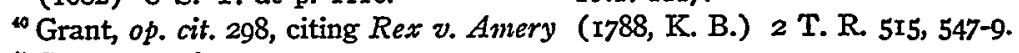

"Grant, op. cit. 295.

"Graint, op. cit. 295, 30r ; cf. (1682) 8 S. T. 1340-43.

${ }_{3}$ Holdsworth, History of English Law, 370, note $\mathrm{I}$.

"In Jolnuson vं. Norway (1622, C. P.) Winch, 37, Hobart, C. J., said that he and the judges would consider whether the land escheated or reverted to the founders; in the Hale MSS., cited in Hargrave's note $7 \mathrm{I}$ to Coke, Littleton * $13 \mathrm{~b}$, it is said that it was finally determined that the land escheated. Gray, Perpetuities (3d ed. I9I5) 45-49. 
the case where the corporation held land in frankalmoign of the donor, in which case it would escheat to the donor..$^{45}$ But there was a disposition in the sixteenth century to apply this rule to all the real property of a corporation. ${ }^{48}$ Coke took this view both in his commentary on Littleton, ${ }^{47}$ and in a case which he decided in $16{ }^{6} 3 ;^{48}$ and he repeated or invented as the cause for the existence of the rule the a priori reason that to all gifts of such property to corporations the law annexed the condition of reverter to the donor. ${ }^{48}$ In this, as in many other cases, Coke fixed the modern law. This rule of reverter to the donor was stated to be law by Lord Hardwicke in $1740 ;^{50}$ Blackstone repeated it, and added the new reason that, as a corporation can have no heirs, a gift to a corporation was in effect a gift to it during its life, and so was analogous to an estate for life $;^{51}$ and it has been accepted by the writers of text books on corporation law, ${ }^{52}$ and applied in a modern case. ${ }^{53}$ Clearly this reason and this analogy applied with even greater force to the leasehold interests held by corporations; for in these cases there was a tenure between them and the lessor. It was assumed in the sixteenth century that a statute was required to prevent the leasehold property of the dissolved monasteries reverting to the donors. $^{54}$ Blackstone stated the rule that they would revert, ${ }^{55}$ and this rule also has been applied in a modern case. ${ }^{56}$ The dissolution of a corporation therefore causes the lease to terminate and to merge in the lessor's estate.

The effect of the dissolution of a corporation on its chattels personal was long unsettled. When Grant wrote in the middle of the nineteenth century opinion was tending in the direction of allowing the Crown to take these chattels as bona vacantia, ${ }^{57}$ and this would seem to be the rule now accepted..$^{58}$ It may be that the acceptance of this rule was

${ }^{45} 3$ Holdsworth, op. cit. 29.

48 (I590) Moore, p. 283, p1. 435, cited Gray, op. cit. 49.

${ }^{47}$ Coke, Littleton, *I3b.

${ }^{s}$ Dean and Canons of Windsor v. Webb (16r3, C. P.) Godbolt, $2 \mathrm{Ir}$.

${ }^{40}$ Coke, Littleton, ${ }_{\text {I } 3 \text { b. }}$.

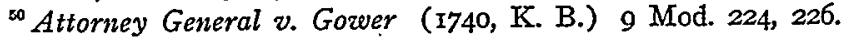

s2 "The grant is indeed only during the life of the corporation; which may endure forever; but, when that life is determined by the dissolution of the body politic, the grantor takes it back by reversion, as in the case of every other grant for life," I Blackstone, Commentaries, *484.

${ }^{52}$ Grant, op. cit. 303.

${ }^{3}$ Re Woking Urban Council [I9I4, C. A.] I Ch. 300; cf. Hastings Corporation v. Letton [I908] I K. B. 378, 387, per Phillimore, J.

${ }^{34}$ See supra, at p. 400.

${ }^{*}$ I Blackstone, Commentaries, ${ }^{*} 484$.

${ }^{56}$ Hastings Corporation v. Letton, supra note 53.

s7 "The personal estate of a dissolved corporation seems to vest in the crown as bona vacantia." Grant, op. cit. 304 .

${ }^{\text {ss }}$ Re Higginson and Dean [1899] I Q. B. 325, 333, per Wright, J.; as he points 
due to a following of the analogy of the equitable rule that if chattels real or personal are vested in a trustee on trusts which fail, they are considered to be bona vacantia, and are therefore held by the trustee on trust for the crown. Obviously the analogy between such a case, and the case where chattels are held on trust for a corporation which has been dissolved is close, and the same rule is applied. ${ }^{59}$ This made it the easier to apply the same rule to the chattels personal which the dissolved corporation held in its own right.

From a very early date it was held that personal rights and liabilities of a dissolved corporation disappeared. Thus rent charges and annuities payable to and by them disappeared $;^{60}$ and $a$ fortiori the same rule applied to such purely personal rights as debts. ${ }^{61}$ It was probably these inconvenient results which followed on a dissolution that induced the courts to hold, wherever possible, that a new charter, given by the crown to a corporation which had become extinct, operates as a revival, so that the rights and liabilities of the old corporation remain. ${ }^{62}$ It is for the same reason that the modern Company Acts make careful provision for the disposal of the Company's property, and for the satisfaction of debts due by and to it, before it can be dissolved. The result is that the law on the subject of the effect of dissolution on a corporation's proprietary position was and still is comparatively meagre.

THE NATURE OF CORPORATE PERSONALITY

The genius of Maitland has popularized in this country the con-. tinental speculations on this topic. The question whether the personality of the corporation is fictitious or real is no doubt an interesting philosophical speculation, and can easily be turned to political account in countries in which, because the trust is unknown, a larger liberty of incorporation is eagerly desired. ${ }^{63}$ But these speculations are for the most part foreign to the province of the lawyer, ${ }^{64}$ and, except so far as such speculations and theories have helped to make our law, they are equally foreign to the province of the legal historian. It will I think be clear from the history of the incorporate person which $I$ have just narrated that English law has, at all periods of its history, been very lightly touched by these speculations. No doubt in the Middle Ages, when the idea of an incorporate person was new, and the law relating to it was

out at p. 33I this contention was made in the argument for the plaintiff in Corporation of Colchester v. Seaber (I766, K. B.) 3 Burr. 1866.

${ }^{\infty}$ Re Higginson and Dean, supra note 58, at p. 329.

${ }^{\infty}$ (I44r) Y. B. 20 Henry VI, p. 7, pl. I7, per Paston and Newton, JJ.; Bishop

of Rochester's Case (1596, C. B.) Owen, 73; Grant, op. cit. 303.

${ }^{o x}$ Ednumnds ข. Brozen (I668; K. B.) I Lev. 237.

- See supra, at p. 403 .

${ }^{\infty}$ See supra, at p. 384 .

os This is well put in H. A. Smith, Law of Associations (1914) 128 et seq. 
comparatively meagre, the lawyers did occasionally indulge in speculations of a crude and somewhat anthropomorphic kind, to help themselves out of the difficulties which they were experiencing in distinguishing this new entity from the human persons who composed it, or, more especially, from the human person who presided over it. ${ }^{65}$ They were hampered both by the novelty of the conception, and the survival of older ideas dating from a time when this distinction had not been clearly grasped. But, during this period, these causes of confu-

- sion were rapidly passing away. Such rules, for instance, as the rule as to the incapacity of a corporation to act while it was without a head, which historically can be traced back to a survival of some of these older ideas, had been placed on a new basis logically consistent with the separate existence of the incorporate person. No doubt the lawyers still occasionally indulge in somewhat vague generalities as to the invisibility, immorality, and other non-natural qualities of this new entity. But they lay no great stress on them. They recognize that, by reason of its nature, some activities which are possible to the natural man are impossible to it; they are beginning to recognize that as a matter of public policy, its activities should be limited to the purposes for which it was created; but, subject to these disqualifications, they have equated it as far as possible with the natural men.

This idea that the corporation is to be treated as far as possible like a natural man is the only theory about the personality of corporations that the common law has ever possessed. It is a large and a vague idea, but, on that very account, it is a flexible idea. It has made it possible to develop the law as to the powers and capacities of corporations according to the needs and public policy of the day. ${ }^{68}$ It has made it possible to discipline them, and render them liable criminally or civilly for their wrongful acts in ways which are appropriate to the politic character of their personality. And the fact that it has thus been possible to make them liable for their wrongful acts has enabled the law to adhere firmly to the central theory of corporation law that the corporation is an artificial entity quite distinct from its members. It has been found possible to punish a corporation by dissolution or suspension of its existence; and it is not the case, as the counsel for the City of London argued in I682, that a corporation cannot be punished, and that, if wrong is done, the individual corporators are alone liable in their individual capacity.

In these last days the danger that an incapacity to deal with a corporation whose activities are mischievous will induce the courts to tamper

\footnotetext{
${ }^{\infty 5} 3$ Holdsworth, History of English Law, 37o, note $\mathrm{r}$.

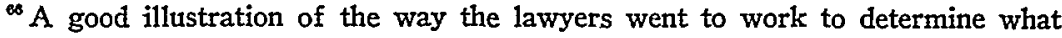
rules of law applicable to natural man should apply to corporations, can be seen in the reasons of expediency advanced in Croft $v$. Howel ( $1578, \mathrm{~K}$. B.) Plowden, 530,538 , for the view that corporations, though not named, are included in Henry VII's Statute of Fines.
} 
with this central theory of corporation law is illustrated by the decision of the House of Lords in the Daimler Case. ${ }^{67}$ This corporation being a limited company, it was not possible to attack it, as it might have been possible to attack a common-law corporation, on the ground that its activities were in the circumstances contrary to public policy. ${ }^{68}$ And so the House of Lords, with an eye to national defence, and in order to do substantial justice, deliberately disregarded the distinction between the corporation and its members, and ruled that, in time of war, the character of its members might, for certain purposes, affect the character of the company. Foreigners might say that the corporation law of a country in which such a decision is possible is as yet in a rudimentary state, as it is clear that the distinction between the personality of a corporation and that of its members is very lightly held. That would not be perhaps a wholly fair criticism; for the decision was largely due to the absence of any power in the crown to proceed against a company, as it might possibly have proceeded against a common-law corporation. $^{69}$ In fact the elastic theory of corporate personality which the common law was developing and applying to common-law corporation during this period, was in theory adequate to deal with corporate shortcomings. In practice it is true, it had its defects, as the Municipal Corporations Report of $\mathrm{I} 833$ was to show. ${ }^{70}$ But the view that the corporation was to be given, so far as was consistent with its artificial nature and with the purposes for which it was created, the capacities and liabilities of the natural man is probably as workable a theory of the nature of corporate personality as can be devised,--provided that the means of enforcing corporate liabilities civil or criminal are adequate, and provided that the law is enforced with vigilance.

${ }^{\pi}[$ [19I6, H. L.] 2 A. C. 307.

es See Grant, op. cit. 42.

- See Mr. McNair's very pertinent criticisms on this decision in his Essays upon Some Legal Effects of War (1920) II7-I20.

${ }^{70}$ See supra, note 73, p. 394. 